\title{
Developmental history of neurorestoratology
}

This article was published in the following Dove Press journal:

Journal of Neurorestoratology

II February 2015

Number of times this article has been viewed

\author{
Hongyun Huang ${ }^{1,2}$ \\ Lin Chen ${ }^{3,4}$ \\ Paul R Sanberg 5
}

'Institute of Neurorestoratology, General Hospital of Armed Police Forces, Beijing, People's Republic of China; ${ }^{2}$ Beijing Rehabilitation Hospital of Capital Medical University, Beijing, People's Republic of China;

${ }^{3} T$ singhua University Yuquan Hospital, Beijing, People's Republic of China; ${ }^{4}$ Medical Center, Tsinghua University, Beijing, People's Republic of China; ${ }^{5}$ Department of Neurosurgery and Brain Repair, University of South Florida, Tampa, FL, USA
Correspondence: Hongyun Huang No. 69 Yongding Road,

Institute of Neurorestoratology, General Hospital of Armed Police Force, Beijing 100039, People's Republic of China Tel +86 I39 I0I I 6608

Email hongyunh@gmail.com

\begin{abstract}
The aim of neurorestoratology is to restore, promote and maintain the integrity of impaired or lost neuronal functions and/or structures, using novel cell-based comprehensive neurorestorative strategies. The purpose of this review is to briefly introduce the developing history of neurorestoratology, which includes neurorestorative strategies, the basis of central nervous system neurorestorable theory, communities in the field of neurorestoratology, and journals related to neurorestoratology.
\end{abstract}

Keywords: neurorestoration, neurorestorative strategies, CNS neurorestorable theory

\section{Introduction}

Neurorestoration took more than 100 years from a method and a branch of neurological science to the establishment of a distinct discipline - neurorestoratology, ${ }^{1}$ which is a discipline to study neural regeneration, repair and replacement of damaged components of the nervous system, neuroplasticity, neuroprotection and neuromodulation, vasculogenesis and recovery mechanisms of immune regulation. Its aim is to restore, promote and maintain the integrity of impaired or lost neuronal functions and/or structures, using novel cell-based comprehensive neurorestorative strategies. Prior to neurorestoratology, which was put forward by Huang and Chen and later approved by the International Association of Neurorestoratology as an independent discipline, ${ }^{1,2}$ historically, there were other similar sub-disciplines or techniques, such as restorative neurology, ${ }^{3}$ restorative neurosurgery, ${ }^{4}$ neural repair, ${ }^{5}$ neuroprostheses, ${ }^{6}$ neurorestorative technique or therapy, and restorative neuroscience, ${ }^{9}$ among others. All of them share a common connotation for neural functional recovery though they display in different appearance. ${ }^{10}$

\section{History of strategies for neurorestoratology}

The strategies of neurorestoratology include tissue and cell transplantation, neurostimulation and neuromodulation, medicine and growth factors, bioengineering and tissue engineering, restorative surgery, and others.

\section{Tissue and cell transplantation}

In 2010, Dunnett classified the tissue and cell transplantation developing process into four sections or eras. ${ }^{11}$

\section{0-1940: the early era}

The first cell transplantation into the brain was attempted during this era. Many contemporary themes were initially addressed, such as surgical factors to achieve survival 
of grafted cells and how that should be assessed. Such studies, however, generally exhibited only low levels of viability or successful implantation. ${ }^{11}$ Thompson reported the earliest tissue transplantation in animals in 1890 with a graft survival of 7 weeks. ${ }^{12}$ Subsequently, Cajal first described the axonal regeneration-promoting effects of peripheral nerve implants in the spinal cord. ${ }^{13}$

\section{0-1970: the middle era}

During this era, the techniques for viable and reliable cell transplantation using embryonic donor tissues implanted into sites with effective vascularization were established in the brain and neuroendocrine systems. ${ }^{11}$ It is noteworthy to comment that in all of these studies, the brain of an adult mammal was chosen as the site for transplantation essentially because it has always been considered as an immunologically privileged site. ${ }^{14-16}$

\section{0-2000: the modern era}

Several pioneering studies that combined cell transplantation with the use of improved histochemical and ultrastructural anatomical techniques demonstrated the selectivity, specificity, and regenerative capacity of implanted cells, and the slow acceptance that the adult brain does exhibit considerable potential for plasticity and repair during this era. The findings have witnessed the identification of reliable and efficient transplantation technologies combined with progressively refined methods of molecular, cellular, biochemical, physiological, and functional analysis. ${ }^{11}$ A preclinical brain tissue transplantation study was shown to reduce motor abnormalities in animals, ${ }^{17,18}$ and a similar study was done by Björklund et al. ${ }^{19}$ David and Aguayo found that axons supported by peripheral nerve segments as 'bridges' between the medulla and spinal cord grew approximately $30 \mathrm{~mm}$. The peripheral nervous system glial environment could help central neurons to express regenerative potential. ${ }^{20}$ The initial olfactory ensheathing cell (OEC) transplantation studies of histological and functional recovery in animals started in the 1990s. Ramón-Cueto and others reported that the regeneration of injured dorsal root axons into the adult spinal cord was possible after OEC transplantation; and OEC transplants successfully led to functional and structural recovery after complete spinal cord transection in adult rats. ${ }^{21,22} \mathrm{~A}$ study by Franklin et al provided the first in vivo evidence that OECs are able to produce peripheraltype myelin sheaths around demyelinated spinal cord axons of an appropriate diameter. ${ }^{23} \mathrm{Li}$ et al reported that cut corticospinal axons grew through the transplant and continued to regenerate into the denervated caudal host tract. Rats with complete transactions, in which the transplanted cells had formed a continuous bridge across the lesion, exhibited directed forepaw reaching on the lesioned side. ${ }^{24}$ During this era, the first clinical trial of neural tissue transplantation was done. $^{25,26}$ In this study, autologous adrenal medullary tissue was transplanted to the striatum in two patients with severe parkinsonism, and some rewarding effects were registered. Subsequently, fetal tissue, including dopamine neuron transplantation was performed, resulting in graft survival and motor function improvement in Parkinson's disease (PD) ${ }^{27-30}$ and Huntington's disease (HD) patients. ${ }^{31-33}$

\section{The 2 I st century: contemporary era}

Cell transplantation has been attempted in more central nervous system (CNS) diseases. Over 30 types of cells and tissues have been successfully used in preclinical experiments. ${ }^{34}$ A number of cell transplantation clinical studies worldwide were started during this period. The earliest clinical trial of cultured human neuronal cell transplantation into brain parenchyma for patients with stroke was done by Kondziolka et al. ${ }^{35}$ The earliest clinical trials or studies of OEC transplantation into spinal cord parenchyma were started for spinal cord injury (SCI) by Huang et al and Rabinovich et al. ${ }^{36,37}$ Olfactory mucosa tissue transplantation was done by Lima et al in 2001. ${ }^{38}$ Two years later, Mackay-Sim et al followed with OEC from mucosa for SCI. ${ }^{39}$ After those pioneering studies, other kind of cells, such as Schwann cells, bone marrow (umbilical cord blood or peripheral blood) mononuclear cells, were used in clinical studies in SCI, ${ }^{40-47}$ multiple sclerosis, ${ }^{48,49}$ stroke sequelae, ${ }^{50,51}$ amyotrophic lateral sclerosis (ALS), ${ }^{52,53}$ cerebral palsy, and others. ${ }^{54-56}$ Although these studies could not cure the sequela of CNS diseases, they strongly suggest that they have been able to restore some neurological functions. In support of these published works as listed above and our own data, we firstly proposed a CNS neurorestorable theory; that is, neurological functions are able to be restored in degenerative diseases and sequela of damage in the CNS. ${ }^{10,34,36,52,57}$

\section{Neurostimulation/neuromodulation and neuroprosthesis}

\section{Brain or spinal cord electrical stimulation}

In 1804, Aldini first reported that cortical stimulation evoked horrible facial grimaces. ${ }^{58,59}$ The first patient treated using brain stimulation was reported by Bartholow in $1874 .^{61}$ Direct electrical stimulation or transcranial direct current stimulation (tDCS) to the cerebral cortex or spinal cord could result in potassium release, ${ }^{62}$ antiapoptotic, angiogenic, and 
antiinflammatory effects, and synaptic plasticity, ${ }^{63,64}$ and induce or promote axon outgrowth ${ }^{65-67}$ to restore motor function. ${ }^{68-70}$ Brain stimulation (called electroshock) was the first therapeutic application for severe psychosis and then for pain in 1954..$^{59,71,72}$ Epidural stimulation of the spinal cord induced stepping-like movements in patients with complete SCI. ${ }^{73,74}$ tDCS is a noninvasive technique and is increasingly being used in the treatments of some neurological and psychiatric conditions, eg, chronic pain, epilepsy, depression, motor rehabilitation after stroke, $\mathrm{SCI}$, and $\mathrm{PD} .^{75}$

\section{Deep brain stimulation}

Initially, deep brain stimulation (DBS) was used as a diagnostic method by Delgado et $\mathrm{al}^{59}$ and as a treatment method for movement disorders (eg, PD) by Bekhtereva et al. ${ }^{59}$ Recent studies have demonstrated the potential for treating epilepsy, depression, and obsessive-compulsive disorder. . $^{59,78,79}$

\section{Magnetic stimulation}

The magnetic stimulator was reported for stimulating neural elements in $1982 .^{80}$ Transcranial magnetic stimulation (TMS) was used in clinics at that time. ${ }^{81}$ In recent years, repetitive TMS has been used as a therapeutic tool for a variety of psychiatric and neurological disorders, such as $\mathrm{PD},{ }^{82} \mathrm{ALS},{ }^{83}$ traumatic brain injury, ${ }^{84}$ stroke,${ }^{85,86}$ pain,,${ }^{87}$ dystonia, ${ }^{88}$ and epilepsy. ${ }^{89}$

\section{Neuroprosthesis}

Nashold et al reported electromicturition using a spinal neuroprosthesis implantation for paraplegia in $1971 .{ }^{90}$ Recently, real brain-machine interfaces with neuroprosthetic limbs have been shown to help patients with long-term paralysis to recover the natural and intuitive command signals for hand placement, orientation, and reaching, allowing them to perform activities of partial daily living. ${ }^{91-94}$

\section{Growth factors and drugs}

Levi-Montalcini and Hamburger discovered that nerve growth factor (NGF) can promote the survival and differentiation of sensory and sympathetic neurons, ${ }^{95-97}$ and was first used in a clinical trial by Olson et al in $1991 .{ }^{98}$ High-dose methylprednisolone therapy showed neuroprotection for SCI in an animal study in 1982 and stimulated Young et al to carry out a clinical trial on this subject in $1988 .^{99}$

\section{Bioengineering and tissue engineering}

Rosenberg et al reported that implanting fibroblasts genetically modified with NGF into rat brains could prevent cholinergic neuron degeneration. ${ }^{100}$ Emerich et al found that transplanting polymer-encapsulated fibroblasts genetically modified with human ciliary neurotrophic factor (CNTF) into striatum had a protective effect in an animal model of HD. ${ }^{101}$ Bloch et al completed a clinical trial for HD by transplanting these polymer-encapsulated cells engineered with CNTF into the brain. ${ }^{102}$ Tuszynski et al reported Phase I clinical trial results of gene therapy with NGF for Alzheimer's disease. ${ }^{103}$

\section{Neurorestorative surgeries Cordotomy or myelotomy}

The first report on cordotomy or myelotomy in an animal study was by Freeman and Wright in 1953, which showed protective effects for injured spinal cords. ${ }^{104}$ In 1984, Tachibana et al performed posterior longitudinal myelotomy for patients with cervical acute complete SCI. ${ }^{105}$

\section{Neurotization or nerve bridging}

Carlsson and Sundin reported reconstructing nerve bridging to the urinary bladder in a paraplegic child in 1967 and reconstructed nerve bridging to the urinary bladder for another two paraplegic patients in 1980. ${ }^{106,107}$ Zhang, Brunelli, and others then improved the surgical technique of neurotization or nerve bridging in clinics for patients with SCI.

\section{Neurorehabilitation}

Brackett first mentioned the rehabilitation for soldiers injured in the war in $1918 .{ }^{108}$ Ueda summarized the rehabilitation in neural diseases in 1963. ${ }^{109}$ Luzhetskaia et al first introduced neurorehabilitation as a therapeutic method for neural diseases and damage in $1974 .{ }^{110}$

\section{Comprehensive cell-based neurorestorative strategies}

The study of combined neurorestorative therapies and comprehensive strategies is now recommended in order to help improve benefits for patients or augment neurological functions. ${ }^{111}$

\section{The basis of CNS neurorestorable theory}

Based on clinical achievements obtained from cell-based neurorestorative therapy, CNS neurorestorable theory was proposed by Huang et al. ${ }^{36}$ Liu and Chambers found intraspinal sprouting of dorsal root axons in cats. ${ }^{112}$ Bechtereva and Zontov found a relationship between 
certain forms of potentials and the variations in brain excitability. ${ }^{113}$ Raisman discovered neuronal plasticity in the septal nuclei of the adult rat. ${ }^{114}$ David and Aguayo reported when peripheral nerve segments were used as 'bridges' between the medulla and spinal cord, axons from neurons at both these levels could grow. ${ }^{20}$ Bornstein and Raine reported remyelination in CNS tissue. ${ }^{115}$ Altman and Das found evidence of postnatal hippocampal neurogenesis in rats. ${ }^{16}$ Young and Flamm reported the beneficial effects or neuroprotection of high-dose corticosteroid treatment on both functional recovery and histopathological appearance of injured spinal cords. ${ }^{117}$ Later on, it was found that axonal sprouting or regeneration, signal modulation, remyelination, and neurogenesis could restore neurological function after CNS damage. ${ }^{118-123}$

As we know, neurorestoratology is established on the basis of the CNS neurorestorable theory. Currently, we know many mechanisms of functional recovery, which include signaling repair or unmasking, neuromodulation, neuroplasticity, neurorepair or remyelination, neuroprotection, neural circuit or network reconstruction, neurosynapsis, neuroreplacement, axonal sprouting or regeneration, neurogenesis or neuroregeneration, angiogenesis, and immunomodulation. ${ }^{34,36,38,124}$

Generally, the patient's functional restoration may originate from some or all of the mechanisms as listed above. But under many conditions, functional recovery may be from neuromodulation or unmasking, neuroprotection, and then from neural circuit reconstruction, neuroplasticity and neurorepair through neurotrophins, immune or inflammatory modulation, or angiogenesis and local microenvironment change, and only in a few cases from neurogenesis or neuroregeneration, axonal sprouting, or regeneration. ${ }^{125,126}$ Neuroreplacement may be an important tool for PD, but may not be a useful method for functional neurorestoration in most other CNS damages or diseases.

In addition, we should point out that overemphasizing the concept of neuroregeneration may be a century directional mistake in this area, because 'neuroregeneration' is not equal to functional recovery. Many people misconstrue that 'neuroregeneration' will bring neurological functional recovery, but actually, it is only one kind of neurorestorative mechanism. Our vision should widen to neurorestoration, instead of solely focusing on 'neuroregeneration'. On the contrary, the concept of neurorestoration surely means neurological functional recovery, which doubtless is the ultimate aim of any physician's treatments. Thus, the scientific term of neurorestoration is more accurate to elucidate and express the real implications of clinical outcome than 'neuroregeneration'.

\section{Community in the field of neurorestoratology}

Nowadays, the main associations or societies in or related with neurorestoratology are: the International Association of Neurorestoratology (IANR), American Society for Neural Therapy and Repair (ASNTR), International Conference on Neural Therapy and Repair (INTR), Global College of Neuroprotection and Neuroregeneration (GCNN), International Society of Restorative Neurology (ISRN), International Neuromodulation Society (INS), the Society for the Study of Neuroprotection and Neuroplasticity (SSNN), Cell Transplant Society (CTS), International Conference on Neuroprotective Agenda, Network of European CNS Transplantation and Restoration (NECTAR), and Asia Pacific Symposium on Neural Regeneration (APSNR), among others.

\section{Journals related to neurorestoratology}

The main international published journals in the field of neurorestoratology include: Journal of Neurorestoratology, Cell Transplantation, Restorative Neurology and Neuroscience, Neuromodulation, American Journal of Neuroprotection and Neuroregeneration, Stem Cells, Clinical Transplantation, Cytotherapy, Cell Medicine, and Neurorehabilitation Neural Repair.

\section{Summary}

Neurorestoratology is an emerging discipline that was put forward on the basis of a CNS neurorestorable theory. Numerous respected pioneers have tried their best to explore a glimmer of light (any possible promoting neurorestorative strategies) in the darkness. Some of them have been trying to spread novel concepts, knowledge, and information by creating societies and journals related to neurorestoration. These important pioneers should be borne in mind forever because of their dedication and great contribution. Today, the CNS neurorestorable door has been successfully opened. The road ahead is still rugged, but we know where we are, and more importantly we know where we will go, because we have already had a roadmap to achieve the goal of longevity and good quality of life for humanity. ${ }^{127}$ 


\section{Disclosure}

The authors report no conflicts of interest in this work.

\section{References}

1. International Association of Neurorestoratology. Beijing declaration of international association of neurorestoratology (IANR). Cell Transplant. 2009; 18:487.

2. Huang H, Chen L. Neurorestoratology - New discipline, new theory and new field. Zhongguo Xiu Fu Chong Jian Wai Ke Za Zhi. 2008;22: 439-445. Chinese.

3. Dimitrijević MR, Kakulas BA, Vrbová G. Recent Achievements in Restorative Neurology. Basel, Switzerland: Karger Publishing House; 1986.

4. Liberson WT. More on restorative neurosurgery. Electromyogr Clin Neurophysiol. 1987;27(6-7):323-325.

5. Neural repair. Based on a discussion meeting. Kolimbari, Crete, March 1987. J Exp Biol. 1987;132:1-289.

6. Keith MW, Peckham PH, Thrope GB, Buckett JR, Stroh KC, Menger V. Functional neuromuscular stimulation neuroprostheses for the tetraplegic hand. Clin Orthop Relat Res. 1988;(233):25-33.

7. Fernández CI, Soto J, González O, González ME, Quijano Z. Neurorestorative techniques as experimental approach to Alzheimer disease treatment. Mol Chem Neuropathol. 1995;24(2-3):241-244.

8. Jiménez-Jiménez FJ, Molina JA. [Neuroprotective and neurorestorative therapy in Parkinson's disease]. Rev Neurol. 1997;25 Suppl 2: S185-S193. Spanish.

9. Andres RH, Meyer M, Ducray AD, Widmer HR. Restorative neuroscience: concepts and perspectives. Swiss Med Wkly. 2008; 138(11-12):155-172.

10. Huang H, Chen L, Sanberg P. Clinical achievements, obstacles, falsehoods, and future directions of cell-based neurorestoratology. Cell Transplant. 2012;21 Suppl 1:S3-S11.

11. Dunnett SB. Chapter 55: neural transplantation. Handb Clin Neurol. 2010;95:885-912.

12. Das GD. Neural transplantation: an historical perspective. Neurosci Biobehav Rev. 1990;14(4):389-401.

13. Cajal SR. Degeneration and Regeneration of the Nervous System (Translated by May RM). London, UK: Oxford University Press; 1928.

14. Greene HS. Compatibility and non-compatibility in tissue transplantation. In: Butler EG, editor. Biological Specificity and Growth. The Twelfth Symposium of the Society for the Study of Development and Growth. Princeton, NJ: Princeton University Press; 1955:177-194.

15. Greene HS. The use of transplanted tissues in biology and histology. In: Bourne GH, editor. In Vivo Techniques in Histology. Baltimore, MD: Williams and Wilkins: 1967:80-112.

16. Oppenheimer JM. Methods and techniques. In: Willier BH, Weiss PA, Hamburger V, editors. Analysis of Development. Philadelphia, PA: WB Saunders Co; 1955:25-38.

17. Olson L, Seiger A. Brain tissue transplanted to the anterior chamber of the eye: 1 . Fluorescence histochemistry of immature catecholamine and 5-hydroxytryptamine neurons reinnervating the rat iris. Z Zellforsch Mikrosk Anat. 1972;135(2):175-194.

18. Perlow M, Freed W, Hoffer B, Seiger A, Olson L, Wyatt R. Brain grafts reduce motor abnormalities produced by destruction of nigrostriatal dopamine system. Science. 1979;204(4393):643-647.

19. Björklund A, Stenevi U, Svendgaard N. Growth of transplanted monoaminergic neurones into the adult hippocampus along the perforant path. Nature. 1976;262(5571):787-790.

20. David S, Aguayo AJ. Axonal elongation into peripheral nervous system "bridges" after central nervous system injury in adult rats. Science. 1981;214(4523):931-933.

21. Ramón-Cueto A, Nieto-Sampedro M. Regeneration into the spinal cord of transected dorsal root axons is promoted by ensheathing glia transplants. Exp Neurol. 1994;127(2):232-244.
22. Ramón-Cueto A, Cordero MI, Santos-Benito FF, Avila J. Functional recovery of paraplegic rats and motor axon regeneration in their spinal cords by olfactory ensheathing glia. Neuron. 2000;25(2):425-435.

23. Franklin RJ, Gilson JM, Franceschini IA, Barnett SC. Schwann cell-like myelination following transplantation of an olfactory bulbensheathing cell line into areas of demyelination in the adult CNS. Glia. 1996;17(3):217-224.

24. Li Y, Field PM, Raisman G. Repair of adult rat corticospinal tract by transplants of olfactory ensheathing cells. Science. 1997; 277(5334):2000-2002.

25. Olson L, Backlund EO, Sedvall G, et al. Intrastriatal chromaffin grafts in experimental and clinical Parkinsonism: first impressions. In: Usdin E, Carlsson A, Dahlström A, Engel J, editors. Catecholamines. Part C. Neuropharmacology and Central Nervous System. Therapeutic Aspects (Neurology and Neurobiology Vol 8C). New York, NY: Alan R Liss, Inc.; 1984:195-201.

26. Backlund EO, Granberg PO, Hamberger B, et al. Transplantation of adrenal medullary tissue to striatum in parkinsonism. First clinical trials. J Neurosurg. 1985;62(2):169-173.

27. Lindvall O, Brundin P, Widner H, et al. Grafts of fetal dopamine neurons survive and improve motor function in Parkinson's disease. Science. 1990;247(4942):574-577.

28. Sawle GV, Bloomfield PM, Björklund A, et al. Transplantation of fetal dopamine neurons in Parkinson's disease: PET [18F]6-L-fluorodopa studies in two patients with putaminal implants. Ann Neurol. 1992;31(2):166-173.

29. Widner H, Tetrud J, Rehncrona S, et al. Bilateral fetal mesencephalic grafting in two patients with parkinsonism induced by 1-methyl-4-phenyl-1,2,3,6-tetrahydropyridine (MPTP). N Engl J Med. 1992;327(22):1556-1563.

30. Freed CR, Greene PE, Breeze RE, et al. Transplantation of embryonic dopamine neurons for severe Parkinson's disease. $N$ Engl J Med. 2001;344(10):710-719.

31. Kopyov OV, Jacques S, Lieberman A, Duma CM, Eagle KS. Safety of intrastriatal neurotransplantation for Huntington's disease patients. Exp Neurol. 1998;149(1):97-108.

32. Bachoud-Lévi AC, Rémy P, Nguyen JP, et al. Motor and cognitive improvements in patients with Huntington's disease after neural transplantation. Lancet. 2000;356(9246):1975-1979.

33. Rosser AE, Barker RA, Harrower T, et al. Unilateral transplantation of human primary fetal tissue in four patients with Huntington's disease: NEST-UK safety report ISRCTN no 36485475. J Neurol Neurosurg Psychiatry. 2002;73(6):678-685.

34. Huang H, Chen L, Sanberg P. Cell therapy from bench to bedside translation in CNS neurorestoratology era. Cell Med. 2010;1(1):15-46.

35. Kondziolka D, Wechsler L, Goldstein S, et al. Transplantation of cultured human neuronal cells for patients with stroke. Neurology. 2000;55(4):565-569.

36. Huang $\mathrm{H}$, Chen $\mathrm{L}$, Wang $\mathrm{H}$, et al. Influence of patients' age on functional recovery after transplantation of olfactory ensheathing cells into injured spinal cord injury. Chin Med J (Engl). 2003;116(10):1488-1491.

37. Rabinovich SS, Seledtsov VI, Poveschenko OV, et al. Transplantation treatment of spinal cord injury patients. Biomed Pharmacother. 2003;57(9):428-433.

38. Lima C, Pratas-Vital J, Escada P, Hasse-Ferreira A, Capucho C, Peduzzi JD. Olfactory mucosa autografts in human spinal cord injury: a pilot clinical study. J Spinal Cord Med. 2006;29(3):191-203; discussion 204-206.

39. Mackay-Sim A, Féron F, Cochrane J, et al. Autologous olfactory ensheathing cell transplantation in human paraplegia: a 3-year clinical trial. Brain. 2008;131(Pt 9):2376-2386.

40. Chernykh ER, Stupak VV, Muradov GM, et al. Application of autologous bone marrow stem cells in the therapy of spinal cord injury patients. Bull Exp Biol Med. 2007;143(4):543-547.

41. Cristante AF, Barros-Filho TE, Tatsui N, et al. Stem cells in the treatment of chronic spinal cord injury: evaluation of somatosensitive evoked potentials in 39 patients. Spinal Cord. 2009;47(10):733-738. 
42. Deda H, Inci MC, Kürekçi AE, et al. Treatment of chronic spinal cord injured patients with autologous bone marrow-derived hematopoietic stem cell transplantation: 1-year follow-up. Cytotherapy. 2008;10(6): $565-574$.

43. Geffner LF, Santacruz P, Izurieta M, et al. Administration of autologous bone marrow stem cells into spinal cord injury patients via multiple routes is safe and improves their quality of life: comprehensive case studies. Cell Transplant. 2008;17(12):1277-1293.

44. Huang H, Xi H, Chen L, Zhang F, Liu Y. Long-term outcome of olfactory ensheathing cell therapy for patients with complete chronic spinal cord injury. Cell Transplant. 2012;21 Suppl 1:S23-S31.

45. Moviglia GA, Fernandez Viña R, Brizuela JA, et al. Combined protocol of cell therapy for chronic spinal cord injury. Report on the electrical and functional recovery of two patients. Cytotherapy. 2006; 8(3):202-209.

46. Park JH, Kim DY, Sung IY, et al. Long-term results of spinal cord injury therapy using mesenchymal stem cells derived from bone marrow in humans. Neurosurgery. 2012;70(5):1238-1247.

47. Wu J, Sun T, Ye C, Yao J, Zhu B, He H. Clinical observation of fetal olfactory ensheathing glia transplantation (OEGT) in patients with complete chronic spinal cord injury. Cell Transplant. 2012;21 Suppl 1: S33-S37.

48. Burt RK, Loh Y, Cohen B, et al. Autologous non-myeloablative haemopoietic stem cell transplantation in relapsing-remitting multiple sclerosis: a phase I/II study. Lancet Neurol. 2009;8(3):244-253.

49. Fassas A, Passweg, JR, Anagnostopoulos A, et al; Autoimmune Disease Working Party of the EBMT (European Group for Blood and Marrow Transplantation). Hematopoietic stem cell transplantation for multiple sclerosis. A retrospective multicenter study. J Neurol. 2002;249(8):1088-1097.

50. Kondziolka D, Steinberg GK, Wechsler L, et al. Neurotransplantation for patients with subcortical motor stroke: a phase 2 randomized trial. J Neurosurg. 2005;103(1):38-45.

51. Lee JS, Hong JM, Moon GJ, Lee PH, Ahn YH, Bang OY; STARTING collaborators. A long-term follow-up study of intravenous autologous mesenchymal stem cell transplantation in patients with ischemic stroke. Stem Cells. 2010;28(6):1099-1106.

52. Huang H, Chen L, Xi H, et al. Fetal olfactory ensheathing cells transplantation in amyotrophic lateral sclerosis patients: a controlled pilot study. Clin Transplant. 2008;22(6):710-718.

53. Martinez HR, Gonzalez-Garza MT, Moreno-Cuevas JE, Caro E, Gutierrez-Jimenez E, Segura JJ. Stem-cell transplantation into the frontal motor cortex in amyotrophic lateral sclerosis patients. Cytotherapy. 2009;11(1):26-34.

54. Chen L, Huang $\mathrm{H}$, Xi H, et al. Intracranial transplant of olfactory ensheathing cells in children and adolescents with cerebral palsy: a randomized controlled clinical trial. Cell Transplant. 2010;19(2): $185-191$.

55. Huang H, Chen L, Xi H, et al. Olfactory ensheathing cells transplantation for central nervous system diseases in 1,255 patients. Zhongguo Xiu Fu Chong Jian Wai Ke Za Zhi. 2009;23(1):14-20. Chinese.

56. Ma Y, Tang C, Chaly T, et al. Dopamine cell implantation in Parkinson's disease: long-term clinical and (18)F-FDOPA PET outcomes. $J$ Nucl Med. 2010;51(1):7-15.

57. Chen L, Chen D, Xi HT, et al. Olfactory ensheathing cell neurorestorotherapy for amyotrophic lateral sclerosis patients: benefits from multiple transplantations. Cell Transplant. 2012;21 Suppl 1:S65-S77.

58. Aldini J. Essai théoriqueet expérimental sur le galvanisme, avec une série d'expériences faites devant des commissaires del'Institut nationale de France, et en divers amphithéâtres anatomiques de Londres. Paris, France: Fournier Fils; 1804.

59. Sironi VA. Origin and evolution of deep brain stimulation. Front Integr Neurosci. 2011;5:42.

60. Bartholow R. Experimental investigations into the functions of the human brain. Am J Med Sci. 1874;134:305-313.

61. Zimmermann M. Electrical stimulation of the human brain. Hum Neurobiol. 1982;1(4):227-229.
62. Cicardo VH, Torino A. Release of potassium by the brain of the dog during electrical stimulation. Science. 1942;95(2477):625.

63. Baba T, Kameda M, Yasuhara T, et al. Electrical stimulation of the cerebral cortex exerts antiapoptotic, angiogenic, and anti-inflammatory effects in ischemic stroke rats through phosphoinositide 3-kinase/Akt signaling pathway. Stroke. 2009;40(11):e598-e605.

64. Rothwell JC. Plasticity in the human motor system. Folia Phoniatr Logop. 2010;62(4):153-157.

65. Borgens RB, Blight AR, Murphy DJ, Stewart L. Transected dorsal column axons within the guinea pig spinal cord regenerate in the presence of an applied electric field. J Comp Neurol. 1986;250(2):168-180.

66. Hamid S, Hayek R. Role of electrical stimulation for rehabilitation and regeneration after spinal cord injury: an overview. Eur Spine J. 2008; 17(9):1256-1269.

67. Li Q, Brus-Ramer M, Martin JH, McDonald JW. Electrical stimulation of the medullary pyramid promotes proliferation and differentiation of oligodendrocyte progenitor cells in the corticospinal tract of the adult rat. Neurosci Lett. 2010;479(2):128-133.

68. Fehlings MG, Tator CH, Linden RD. The effect of direct-current field on recovery from experimental spinal cord injury. J Neurosurg. 1988; 68(5):781-792.

69. Carmel JB, Berrol LJ, Brus-Ramer M, Martin JH. Chronic electrical stimulation of the intact corticospinal system after unilateral injury restores skilled locomotor control and promotes spinal axon outgrowth. J Neurosci. 2010;30(32):10918-10926.

70. Polanía R, Paulus W, Nitsche MA. Modulating cortico-striatal and thalamo-cortical functional connectivity with transcranial direct current stimulation. Hum Brain Mapp. 2012;33(10):2499-2508.

71. Cerletti U. L'elettroshock. Riv Sper Freniatr Med Leg Alien Ment. 1940;64:209-310.

72. Wallace BA, Ashkan K, Benabid AL. Deep brain stimulation for the treatment of chronic, intractable pain. Neurosurg Clin N Am. 2004; 15(3):343-357, vii.

73. Minassian K, Jilge B, Rattay F, et al. Stepping-like movements in humans with complete spinal cord injury induced by epidural stimulation of the lumbar cord: electromyographic study of compound muscle action potentials. Spinal Cord. 2004;42:401-416.

74. von Wild K, Rabischong P, Brunelli G, Benichou M, Krishnan K. Computer added locomotion by implanted electrical stimulation in paraplegic patients (SUAW). Acta Neurochir Suppl. 2002;79: 99-104.

75. Knotkova H, Cruciani RA. Non-invasive transcranial direct current stimulation for the study and treatment of neuropathic pain. Methods Mol Biol. 2010;617:505-515.

76. Delgado JM, Hamlin H, Chapman WP. Technique of intracranial electrode implacement for recording and stimulation and its possible therapeutic value in psychotic patients. Confin Neurol. 1952;12(5-6): 315-319.

77. Bekhtereva NP, Grachev KV, Orlova AN, Iatsuksl. [Utilization of multiple electrodes implanted in the subcortical structure of the human brain for the treatment of hyperkinesis]. Zh Nevropatol Psikhiatr Im $S$ S Korsakova. 1963;63:3-8. Russian.

78. Dowling J. Deep brain stimulation: current and emerging indications. Mo Med. 2008;105(5):424-428.

79. Coffey RJ. Deep brain stimulation devices: a brief technical history and review. Artif Organs. 2009;33(3):208-220.

80. Polson MJ, Barker AT, Freeston IL. Stimulation of nerve trunks with time-varying magnetic fields. Med Biol Eng Comput. 1982;20(2): 243-244.

81. Barker AT, Jalinous R, Freeston IL. Non-invasive magnetic stimulation of the human motor cortex. Lancet. 1985;1(8437):1106-1107.

82. Strafella AP, Ko JH, Monchi O. Therapeutic application of transcranial magnetic stimulation in Parkinson's disease: the contribution of expectation. Neuroimage. 2006;31(4):1666-1672.

83. Di Lazzaro V, Dileone M, Pilato F, et al. Repetitive transcranial magnetic stimulation for ALS. A preliminary controlled study. Neurosci Lett. 2006;408(2):135-140. 
84. Pape TL, Rosenow J, Lewis G. Transcranial magnetic stimulation: a possible treatment for TBI. J Head Trauma Rehabil. 2006;21(5): 437-451.

85. Lefaucheur JP. Stroke recovery can be enhanced by using repetitive transcranial magnetic stimulation (rTMS). Neurophysiol Clin. 2006;36(3):105-115.

86. Zhang X, Mei Y, Liu C, Yu S. Effect of transcranial magnetic stimulation on the expression of c-Fos and brain-derived neurotrophic factor of the cerebral cortex in rats with cerebral infarct. J Huazhong Univ Sci Technolog Med Sci. 2007;27(4):415-418.

87. Lefaucheur JP. The use of repetitive transcranial magnetic stimulation (rTMS) in chronic neuropathic pain. Neurophysiol Clin. 2006; 36(3):117-124

88. Tyvaert L, Houdayer E, Devanne H, Monaca C, Cassim F, Derambure P. The effect of repetitive transcranial magnetic stimulation on dystonia: a clinical and pathophysiological approach. Neurophysiol Clin. 2006; 36(3):135-143.

89. Fregni F, Otachi PT, Do Valle A, et al. A randomized clinical trial of repetitive transcranial magnetic stimulation in patients with refractory epilepsy. Ann Neurol. 2006;60(4):447-455.

90. Nashold BS, Friedman H, Glenn JF, Grimes JH, Barry WF, Avery R. Electromicturition in paraplegia: implantation of a spinal neuroprosthesis. Proc Veterans Adm Spinal Cord Inj Conf. 1971;18:161-165.

91. Collinger JL, Wodlinger B, Downey JE, et al. High-performance neuroprosthetic control by an individual with tetraplegia. Lancet. 2013;381(9866):557-564.

92. Hochberg LR, Serruya MD, Friehs GM, et al. Neuronal ensemble control of prosthetic devices by a human with tetraplegia. Nature. 2006;442(7099):164-171.

93. Onose G, Grozea C, Anghelescu A, et al. On the feasibility of using motor imagery EEG-based brain-computer interface in chronic tetraplegics for assistive robotic arm control: a clinical test and long-term post-trial follow-up. Spinal Cord. 2012;50(8):599-608.

94. Simeral JD, Kim SP, Black MJ, Donoghue JP, Hochberg LR. Neural control of cursor trajectory and click by a human with tetraplegia 1000 days after implant of an intracortical microelectrode array. J Neural Eng. 2011;8(2):025027.

95. Cohen S, Levi-Montalcini R, Hamburger V. A nerve growth-stimulating factor isolated from sarcom as 37 and 180. Proc Natl Acad Sci USA 1954;40(10):1014-1018.

96. Cohen S, Levi-Montalcini R. Purification and properties of a nerve growth-promoting factor isolated from mouse sarcoma 180. Cancer Res. 1957;17(1):15-20.

97. Levi-Montalcini R, Hamburger V. Selective growth stimulating effects of mouse sarcoma on the sensory and sympathetic nervous system of the chick embryo. J Exp Zool. 1951;116(2):321-361.

98. Olson L, Backlund EO, Ebendal T, et al. Intraputaminal infusion of nerve growth factor to support adrenal medullary autografts in Parkinson's disease. One-year follow-up of first clinical trial. Arch Neurol 1991;48(4):373-381.

99. Young W, DeCrescito V, Flamm ES, Blight AR, Gruner JA. Pharmacological therapy of acute spinal cord injury: studies of high dose methylprednisolone and naloxone. Clin Neurosurg. 1988;34: 675-697.

100. Rosenberg MB, Friedmann T, Robertson RC, et al. Grafting genetically modified cells to the damaged brain: restorative effects of NGF expression. Science. 1988;242(4885):1575-1578.

101. Emerich DF, Winn SR, Hantraye PM, et al. Protective effect of encapsulated cells producing neurotrophic factor CNTF in a monkey model of Huntington's disease. Nature. 1997;386(6623):395-399.

102. Bloch J, Bachoud-Lévi AC, Déglon N, et al. Neuroprotective gene therapy for Huntington's disease, using polymer-encapsulated cells engineered to secrete human ciliary neurotrophic factor: results of a phase I study. Hum Gene Ther. 2004;15(10):968-975.

103. Tuszynski MH, Thal L, Pay M, et al. A phase 1 clinical trial of nerve growth factor gene therapy for Alzheimer disease. Nat Med. 2005;11(5):551-555.
104. Freeman LW, Wright TW. Experimental observations of concussion and contusion of the spinal cord. Ann Surg. 1953;137(4): 433-443.

105. Tachibana S, Okada K, Ohwada T, Yada K. [Posterior longitudinal myelotomy as a surgical treatment of acute cervical spinal cord injury]. No Shinkei Geka. 1984;12(2):183-188. Japanese.

106. Carlsson CA, Sundin T. Reconstruction of efferent pathways to the urinary bladder in a paraplegic child. Rev Surg. 1967;24(1):73-76.

107. Carlsson CA, Sundin T. Reconstruction of afferent and efferent nervous pathways to the urinary bladder in two paraplegic patients. Spine (Phila Pa 1976). 1980;5(1):37-41.

108. Brackett EG. Rehabilitation of diseased and injured soldiers to the war. Am J Public Health (NY). 1918;8(1):11-13.

109. Ueda S. [Rehabilitation in neural diseases, with emphasis on apoplexy]. Sogo Igaku. 1963;20:107-120. Japanese.

110. Luzhetskaia TA, Gorbunov FE, Knyshenko VI. [Neurorehabilitation]. Med Sestra. 1974;33(10):15-20. Russian.

111. Huang H. Progress in cellular neurorestoratology: a brief introduction to the IANR supplement Issue. Cell Transplant. 2013;22 Suppl 1: $\mathrm{S} 1-\mathrm{S} 3$.

112. Liu CN, Chambers WW. Intraspinal sprouting of dorsal root axons; development of new collaterals and preterminals following partial denervation of the spinal cord in the cat. AMA Arch Neurol Psychiatry. 1958;79(1):46-61.

113. Bechtereva NP, Zontov VV. The relationship between certain forms of potentials and the variations in brain excitability (based on EEG, recorded during photic stimuli triggered by rhythmic brain potentials). Electroencephalogr Clin Neurophysiol. 1962;14:320-330.

114. Raisman G. Neuronal plasticity in the septal nuclei of the adult rat. Brain Res. 1969;14(1):25-48.

115. Bornstein MB, Raine CS. Experimental allergic encephalomyelitis: demyelination, remyelination and sclerosis in cultured mammalian CNS tissue. Trans Am Neurol Assoc. 1969;94:46-47.

116. Altman J, Das GD. Autoradiographic and histological evidence of postnatal hippocampal neurogenesis in rats. J Comp Neurol. 1965;124(3):319-335.

117. Young W, Flamm ES. Effect of high-dose corticosteroid therapy on blood flow, evoked potentials, and extracellular calcium in experimental spinal injury. J Neurosurg. 1982;57(5):667-673.

118. Bechtereva NP, Bondartchuk AN, Smirnov VM, Meliutcheva LA, Shandurina AN. Method of electrostimulation of the deep brain structures in treatment of some chronic diseases. Confin Neurol. 1975; 37(1-3):136-140.

119. Bendel O, Bueters T, von Euler M, Ove Ogren S, Sandin J, von Euler G. Reappearance of hippocampal CA1 neurons after ischemia is associated with recovery of learning and memory. J Cereb Blood Flow Metab. 2005;25(12):1586-1595.

120. Croll RP, Baker MW. Axonal regeneration and sprouting following injury to the cerebral-buccal connective in the snail Achatina fulica. J Comp Neurol. 1990;300(2):273-286.

121. Honmou O, Felts PA, Waxman SG, Kocsis JD. Restoration of normal conduction properties in demyelinated spinal cord axons in the adult rat by transplantation of exogenous Schwann cells. J Neurosci. 1996;16(10):3199-3208

122. Naftchi NE. Functional restoration of the traumatically injured spinal cord in cats by clonidine. Science. 1982;217(4564):1042-1044.

123. Palladini G, Caronti B, Pozzessere G, et al. Treatment with cyclosporine A promotes axonal regeneration in rats submitted to transverse section of the spinal cord - II - Recovery of function. J Hirnforsch. 1996;31(1):145-153.

124. Karussis D, Karageorgiou C, Vaknin-Dembinsky A, et al. Safety and immunological effects of mesenchymal stem cell transplantation in patients with multiple sclerosis and amyotrophic lateral sclerosis. Arch Neurol. 2010;67(10):1187-1194.

125. Toft A, Scott DT, Barnett SC, Riddell JS. Electrophysiological evidence that olfactory cell transplants improve function after spinal cord injury. Brain. 2007;130(Pt 4):970-984. 
126. Yamamoto M, Raisman G, Li D, Li Y. Transplanted olfactory mucosal cells restore paw reaching function without regeneration of severed corticospinal tract fibres across the lesion. Brain Res. 2009;1303: 26-31.
127. Huang H, Sharma HS. Neurorestoratology: one of the most promising new disciplines at the forefront of neuroscience and medicine. J Neurorestoratol. 2013;1:37-41.

\section{Publish your work in this journal}

The Journal of Neurorestoratology is an international, peer-reviewed, open access online journal publishing original research and review articles on the subject of Neurorestoratology. To provide complete coverage of this revolutionary field the Journal of Neurorestoratology will report on relevant experimental research, technological advances, and clinical achievements. The manuscript management system is completely online and includes a very quick and fair peer-review system, which is all easy to use. Visit http://www.dovepress.com/testimonials.php to read real quotes from published authors.

Submit your manuscript here: http://www.dovepress.com/journal-of-neurorestoratology-journal 